\title{
EFEKTIFITAS PENDIDIKAN KESEHATAN METODE DEMONSTRASI DAN MEDIA VIDEO TERHADAP PRAKTIK SADARI DI PONDOK PESANTREN DARUL HIJRAH PUTRI MARTAPURA
}

\section{THE EFFECTIVENESS OF HEALTH EDUCATION DEMONSTRATION METHOD AND VIDEO MEDIA ON BSE PRACTICE IN DARUL HIJRAH BOARDING SCHOOL FOR FEMALE MARTAPURA}

\author{
H.Ruslinawati ${ }^{1}$ \\ Darmayanti Wulandatika² \\ Nisrina Nadya Wahda ${ }^{3}$ \\ Program Studi S.1 Keperawatan Fakultas Keperawatan dan Ilmu Kesehatan Universitas Muhammadiyah \\ Banjarmasin \\ E-mail: inaruslinawati@yahoo.com
}

\begin{abstract}
ABSTAK
Deteksi dini kanker payudara dengan SADARI dapat dilakukan sendiri untuk mengenali kelainan pada payudara, dilakukan berkala setiap bulan, pada hari ke-7 sampai ke-10 setelah mentruasi, tindakannya meliputi: posisi, inspeksi, palpasi dan pola, namun masih banyak yang belum tahu tentang SADARI dan masih tingginya kasus kanker payudara pada tahun 2018 mencapai 542 kasus di Indonesia. Untuk menekan tingginya kasus kanker payudara, pendidikan kesehatan tentang SADARI perlu dilakukan. Menganalisis efektifitas pendidikan kesehatan metode demonstrasi dan media video terhadap praktik SADARI. Rancangan penelitian ini Quasy Eksperimental dengan Posttest Only Control Group Design, populasi seluruh santriwati kelas XI sejumlah 216 diambil dengan metode Proporsional Stratified Random Sampling sebanyak 68 orang yang dibagi menjadi kelompok demonstrasi dengan video dan kelompok video. Hasil uji statistik mengguakan uji Mann Whitney. Terdapat perbedaan efektifitas yang signifikan antara pendidikan kesehatan metode demonstrasi dengan media video dan media video saja, dimana nilai $p$ value $0.033<0,05$. Pendidikan kesehatan metode demonstrasi dengan media video lebih efektif terhadap praktik SADARI daripada pendidikan kesehatan dengan media video saja.
\end{abstract}

Kata kunci : Pendidikan Kesehatan, Demonstrasi, Video, SADARI

\begin{abstract}
ABSTRAC
Early detection of breast cancer with BSE can be done alone to recognize abnormalities in the breast, carried out periodically every month, on the 7th to 10th day after menstruation, the actions include: position, inspection, palpation and patterns. However, there are still many who do not know about BSE and the high number of breast cancer cases in 2018 reaching 542 cases in Indonesia. To reduce the high cases of breast cancer, health education about BSE needs to be done. Analyze the effectiveness of health education demonstration methods and video media on BSE practices. The Quasy Experimental research design, the Posttest Only Control Group Design, the total population of class XI is 216 students were taken by the Proportional Stratified Random Sampling Method with 68 people divided into demonstration with video groups and video groups, the statistical test results using the Mann Whitney test. There is a significant difference in effectiveness between health education demonstration methods with video media and video media only, where the $p$ value is $0.033<0.05$. Demonstration health education with video media is more effective against BSE practices than health education with video media only.
\end{abstract}

Keywords: Health Education, Demonstrations, Video, BSE 


\section{PENDAHULUAN}

Periksa Payudara Sendiri (SADARI) merupakan salah satu cara pendeteksian dini terhadap kanker payudara yang dicanangkan World Health Organisation (WHO) dan Kementrian Kesehatan Republik Indonesia (Kemeneks RI). SADARI adalah metode termudah, tercepat, termurah dan paling sederhana yang dapat mendeteksi dini adanya kelainan pada payudara yang merupakan cikal bakal dari kanker payudara.

Menurut Kemenkes $\mathrm{Rl}$ kasus kanker payudara terus meningkat sejak tahun 2015 dan pada tahun 2019 terdata 42 dari 100.000 wanita terdiagnosis kanker payudara dengan kasus kematian $17: 100.000$ wanita. Data dari Dinas Kesehatan Kalimantan Selatan menunjukkan terdapat 542 kasus pada tahun 2018. Hal ini dikarenakan sebagian besar wanita masih belum mengetahui tentang pemeriksaan dini kanker payudara dengan SADARI. WHO mengatakan satu-satunya cara yang efektif sampai saat ini hanya dengan melakukan deteksi sedini mungkin pada kemungkinan timbulnya penyakit ini, yaitu dengan melakukan SADARI. Tindakan ini sangat penting karena hampir $85 \%$ benjolan payudara ditemukan oleh penderita sendiri (Purba, 2013).

Menurut riset dari Kemenkes RI (2017), seiring perkembangan zaman, wanita berusia muda atau remaja pun beresiko tinggi terdiagnosis kanker payudara. Salah satunya dikarenakan faktor usia menarche yange terlalu muda (Astuti, 2017). Usia menarche kurang dari 12 tahun menyebabkan paparan hormon esterogen pada tubuh menjadi lebih cepat. Hormon esterogen dapat memicu pertumbuhan sel pada bagian tubuh tertentu seperti payudara secara tidak normal sehingga di perlukan SADARI sejak pertama kali menstruasi. Membuat SADARI akan lebih efektif jika dilakukan sedini mungkin rata-rata ketika wanita mencapai usia reproduksi yaitu 15 - 49 tahun (Ardayani \& Sinaga, 2016).

Memberikan pendidikan kesehatan tentang SADARI merukakan cara agar remaja mengetahui dan mau melakukan SADARI sebagai pendeteksian dini kanker payudara. Pendidikan kesehatan menjadi efektif dan menarik bila menggunakan metode dan media yang bervariasi. Salah satunya dengan demonstrasi dan video. Dimana Keuntungan dari metode demonstrasi yaitu dapat meningkatkan motivasi dan menghidupkan pelajaran karena responden tidak hanya mendengar tetapi juga melihat peristiwa yang terjadi (Segala, 2011). Sedangkan Keuntungan dari media video yaitu dapat membuat proses pembelajaran menjadi lebih jelas dan lebih konkret, lebih mudah memahami sesuatu, lebih menarik, peserta didik dirangsang untuk mengamati, menyesuaikan teori dengan kenyataan dan dapat melakukan sendiri (Mubarak, 2012).

Hasil studi pendahuluan yang dilakukan pada September 2019 kepada 10 santriwati Pondok Pesantren Darul Hijrah Putri Martapura terkait dengan SADARI, 2 siswi diantaranya tahu namun belum pernah melakukan praktik SADARI, sedangkan 8 siswi lainnya belum mengetahui SADARI dan belum pernah melakukan praktik SADARI.

Berdasarkan uraian diatas peniti tertarik untuk melakukan penelitian tentang efektifitas pendidikan kesehatan metode demonstasi dan media video terhadap praktik SADARI Di Pondok Pesantren Darul Hijrah Putri Martapura.

\section{Metode Penelitian}

Penelitian ini menggunakan quasyexperimental dengan rancangan nonequivalent posttest-only control group design. Populasi penelitian ini adalah santriwati kelas XI di Pondok Pesantren Darul Hijrah Putri Martapura pada tahun 2019 sejumlah 216 dan diambil dengan metode Proporsional Stratified Random Sampling sebanyak 68 orang yang dibagi menjadi kelompok demonstrasi dan video dan kelompok video. Instrumen penelitian menggunakan lembar checklist observasi tentang SADARI.Untuk menganalisis perbedaan pendidikan kesehatan metode demonstrasi dengan media video dan pendidikan kesahatan media video menggunakan kolerasi mann whitney. Sebelum proses pengumpulan data penelitian ini terlebih dahulu melewati proses uji etik penelitian dan dinyatakan lulus dengan No. sertifikat 147/UMBKE/X/2019. 


\section{Hasil Penelitian}

\subsection{Analisis Univariat}

Tabel 1. Kemampuan praktik SADARI

setelah diberikan pendidikan kesehatan metode demonstrasi dengan media video di

Pondok Pesantren Darul Hijrah Putri Martapura

\begin{tabular}{cccc}
\hline No & Nilai & Frekuensi & Presentase \\
\hline 1 & 100 & 11 & $32 \%$ \\
2 & 94,4 & 4 & $12 \%$ \\
3 & 88,9 & 5 & $15 \%$ \\
4 & 83,3 & 6 & $17 \%$ \\
5 & 77,8 & 5 & $15 \%$ \\
6 & 72,2 & 1 & $3 \%$ \\
7 & 61,1 & 2 & $6 \%$ \\
\hline Total & & 34 & $100 \%$ \\
\hline Mean & 88,409 & &
\end{tabular}

Berdasarkan tabel 1 dapat dilihat bahwa mayoritas responden dengan nilai tertinggi 100 yaitu sebanyak 11 orang $(32 \%)$ dan nilai terendah untuk kelompok intervensi adalah 61,1 sebanyak 2 orang $(6 \%)$.

Tabel 2. Kemampuan praktik SADARI setelah diberikan pendidikan kesehatan dengan media video di Pondok Pesantren Darul Hijrah Putri Martapura

\begin{tabular}{cccc}
\hline No & Nilai & Frekuensi & Presentase \\
\hline 1 & 100 & 9 & $26 \%$ \\
2 & 94,4 & 1 & $3 \%$ \\
3 & 88,9 & 4 & $11 \%$ \\
4 & 83,4 & 4 & $12 \%$ \\
5 & 72,2 & 3 & $9 \%$ \\
6 & 66,7 & 4 & $12 \%$ \\
7 & 61,1 & 4 & $12 \%$ \\
8 & 55,6 & 3 & $9 \%$ \\
9 & 44,4 & 1 & $3 \%$ \\
10 & 27,8 & 1 & $3 \%$ \\
\hline Total & & 34 & $100 \%$ \\
\hline Mean & 77,950 & & \\
\hline
\end{tabular}

Berdasarkan tabel 2. dapat dilihat bahwa mayoritas responden dengan nilai tertinggi 100 yaitu sebanyak 9 orang (26\%) dan nilai terendah untuk kelompok kontrol adalah 27,8 sebanyak 1 orang $(3 \%)$.

\section{Analisis Bivariat}

Tabel 3. Perbedaan efektifitas pendidikan kesehatan metode demonstrasi dengan media video dan pendidikan kesehatan media video terhadap praktek SADARI

\begin{tabular}{cccc}
\hline Kelompok & Mean Rank & $\begin{array}{c}\text { Selisih Mean } \\
\text { Rank }\end{array}$ & $\begin{array}{c}\text { Asymp. Sig. } \\
\text { (2-tailed) }\end{array}$ \\
\hline Intervensi & 39,53 & 10,06 & .033 \\
Kontrol & 29,47 & & .03 \\
\hline
\end{tabular}

Berdasarkan tabel 3. didapatkan hasil bahwa didalam penelitian ini menunjukkan bahwa pendidikan kesehatan metode demosntrasi dengan media video $(39,53)$ lebih efektif daripada pendidikan kesehatan media video saja $(29,47)$. Hasil uji Mann Whitney dengan taraf signifikan $(\alpha)=0,01$ menghasilkan nilai $p$ - value $=0,033$ dan dimana $p>0,01$. Bahwa terdapat perbedaan efektifitas pendidikan kesehatan metode demonstrasi dengan media video dan pendidikan kesehatan media video terhadap praktek SADARI di Pondok Pesantren Darul Hijrah Putri Martapura.

\section{Pembahasan \\ Kemampuan praktik SADARI remaja putri setelah diberikan pendidikan kesehatan metode demonstrasi dengan media video di Pondok Pesantren Darul Hijrah Putri Martapura}

Menurut hasil penelitian ini, pendidikan kesehatan metode demosntrasi dengan media video efektif terhadap kemampuan praktik SADARI. Hal ini dikarenakan salah satu faktor yang mempengaruhi kemampuan SADARI adalah pengetahuan yang telah didapatkan. Pendidikan kesehatan menggukanan video dan demonstrasi memberikan informasi tentang SADARI yang meningkatkan pengetahuan SADARI pada remaja sehingga mereka mampu melakukan praktik SADARI. Sesuai dengan teori Notoatmojo (2007) mengatakan bahwa informasi dalam bentuk pendidikan kesehatan dapat mempengaruhi tingkat pengetahuan. Maka dengan memberikan pendidikan kesehatan dengan media video dan demonstrasi tentang SADARI akan meningkatkan pengetahuan responden tentang praktik SADARI. Sehingga responden mampu melakukan praktik SADARI sesuai dengan informasi yang telah diterima. Penelitian yang dilakukan Wahyuningtiyas (2012) menunjukkan bahwa pengetahuan adalah faktor utama yang mempengaruhi keterampilan melakukan SADARI. Alasan pengetahuan dapat mempengaruhi keterampilan melakukan SADARI karena dengan pengetahuan, responden dapat memahami dan mengetahui cara melakukan SADARI yang benar, sehingga responden lebih mudah melakukan SADARI. Sejalan dengan penelitian yang dilakukan Pradani et al, (2017) mengatakan bahwa Ada pengaruh efektifitas pendidikan kesehatan dengan metode demonstrasi dan media audio visual (video) terhadap ketrampilan praktik SADARI di SMK Batik 2 Surakarta. 
Nilai tertinggi didapatkan oleh 11 orang (32\%) yaitu 100. Hal ini karena teknik penyampaian informasi dengan pendidikan kesehatan metode demonstrasi dengan media video yang menarik sehingga mampu meningkatkan minat dan penyerapan informasi responden yang tinggi. Responden diberikan video berupa sebuah cerita dengan penggambaran animasi serta suara tentang SADARI sebagai stimulus, video animasi ini dapat meningkatkan ketertarikan dan minat responden sehingga termotivasi untuk melakukan praktik SADARI. Sejalan dengan penelitian Supriadi et al (2014) mengatakan bahwa media video lebih efektif dalam meningkatkan perilaku praktik SADARI pada siswi kelas XI SMA.

Setelah diberikan video responden diberikan demonstrasi praktik SADARI menggunakan alat peraga nyata atau tubuh manusia. Responden diminta untuk mengikuti demonstrastor sehingga selain responden mampu melihat secara langsung langkah SADARI yang telah mereka lihat di video, responden juga dapat mengikuti gerakan yang mereka lihat. Menurut Trianto (2016), Metode demonstari dapat mendorong motivasi dan meningkatkan minat karena demonstrasi dapat menghidupkan pendidikan kesehatan, responden tidak hanya mendengar tapi juga melihat peristiwa yang terjadi. Kelebihan metode demonstrasi salah satunya adalah materi yang diberikan lebih jelas dan konkret, sehingga menghindari verbalisme dan kesalahankesalahan yang terjadi di video dapat diperbaiki melaui pengamatan dengan objek sebenarnya (Djamarah, 2010). Hal ini dapat disimpukan bahwa dengan penggabungan video dan demonstrasi berpengaruh terhadap pengetahuan sehingga meningkatkan minat untuk mampu melakukan praktik SADARI dan efektif mempengaruhi kemampuan SADARI pada remaja putri. Sejalan dengan penelitian Pramadani (2017), yang menyatakan bahwa ada pengaruh efektifitas pendidikan kesehatan dengan metode demonstrasi dan media audio visual (video) terhadap ketrampilan praktik SADARI di SMK Batik 2 Surakarta dengan nilai P value; $0,001<0,005$. 11 orang tersebut mampu melakukan seluruh langkah SADARI mulai dari berdiri didepan cermin, memperhatikan kondisi payudara, mencubit puting, meraba ketiak dengan gerakan memutar seperti obat nyamuk sampai puncak payudara hingga pemeriksaan payudara dengan posisi rebahan.
Nilai terendah yang didapatkan kelompok intervensi adalah 61.1 pada 2 orang (6\%) dari 34 responden. Hal ini bisa disebabkan karena kelemahan dari demonstrasi yaitu apabila dilakukan di ruangan yang besar sehingga responden sukar melihat demonstrasi dengan jelas (Djamarah, 2010) sehingga informasi yang diberikan tidak tersampaikan dengan sempurna, indra pengelihatan responden terhalang. Hal ini akan berpengaruh pada kemampuan menyerap informasi responden sesuai dengan penelitian Supriadi (2014) yang mengatakan Walaupun melibatkan sebagian panca indra tetapi hal ini tergantung dari kemampuan si penerima informasi. 2 responden ini mampu melakukan 11 dari 18 langkah SADARI dengan rata-rata langkah yang tidak mampu dilakukan adalah mengangkat kedua tangan, meletakkan kedua tangan dipunggang lalu merunduk untuk melihat kondisi payudara dan mencubit lembut untuk melihat apakah ada cairan yang keluar.

\section{Kemampuan praktik SADARI setelah diberikan pendidikan kesehatan dengan media video di Pondok Pesantren Darul Hijrah Putri Martapura}

Hasil penelitian ini munjukkan bahwa setelah diberikan pendidikan kesehatan media video kepada 34 responden pada kelompok kontrol didapatkan nilai tertinggi yang didapat kelompok kontrol adalah 100 yang didapatkan oleh 9 (26\%) dari 34 responden. Hal ini menunjukkan bahwa pendidikan kesehatan dengan media video efektif mempengaruhi kemampuan praktik SADARI di Pondok Pesantren Darul Hijrah Putri Martapura. Responden merupakan santriwati yang sudah terbiasa dengan system belajar menghapal yang diterapkan di pondok untuk menghapal ayat ayat Al-Qur'an dan hadist. Media video mampu menarik minat reponden dan meningkatkan motivasi untuk melakukan praktik SADARI sebagai pendeteksi dini dan pencegahan kematian akibat kanker payudara. sesuai dengan pendapat Yakout et all (2014), dimana kesadaran untuk melakukan SADARI penting ditumbuhkan untuk memotivasi seseorang agar secara teratur melakukan SADARI untuk megidentifikasi secara dini benjolan abnormal pada payudaranya sehingga dapat segera diobati dan mencegah kematian karenanya. Menurut Arsyad (2009) Responden dapat menyerap materi yang didapat dari Video sebanyak diatas $60-80 \%$ sejalan dengan penelitian Widiyatmiko (2015), mengatakan bahwa tingkat efektifitas 
menggukana media AVA (video) sebesar $79,02 \%$ sampai $83,37 \%$ pada hasil belajar siswa. Penelitian yang dilakukan Zen (2016) mengatakan bahwa penyuluhan SADARI mengunakan video dapat meningkatkan kemampuan melakukan SADARI pada anggota PMR SMA N 1 Jetis Bantul dengan $p$ value 0,000 .

$2(6 \%)$ dari 34 responden mendapatkan nilai terendah yaitu 44,4 dan 27,8 diartikan responden mampu melakukan 5 dari 18 langkah SADARI berupa berdiri di depan cermin, menempatkan kedua tangan dipinggang, mengangkat sebelah tangan, pada posisi berbaring meletakkan bantalan disisi payudara yang akan diperiksa, mengangkat sebelah tangan dan meraba ketiak dengan gerakan memutar seperti obat nyamuk hingga puncak payudara tapi hanya dilakukan pada satu sisi. Hal ini dikarenakan video yang diputar cepat dan sebentar, durasi video yang diberikan adalah 10 menit. Kelemahan video sebagai media pendidikan kesehatan menurut Kustandi \& Sutjipto (2013), pada saat diputarkan video gambar dan suara yang berjalan terus sehingga tidak semua responden mampu mengikuti informasi yang disampaikan oleh video tersebut sehingga responden tertinggal informasi dan tidak mampu mengingat semua informasi yang didapat. Sejalan dengan penelitian Primareva (2014), mengatakan bahwa pembelajaran menggunakan media video tidak mampu meningkatkan kemampuan mengingat responden.

\section{Perbedaan efektifitas pendidikan kesehatan metode demonstrasi dan media video terhadap praktik SADARI antara kelompok intervensi dan kelompok kontrol di Pondok Pesantren Darul Hijrah Putri Martapura}

Hasil penelitian ini menunjukkan bahwa pendidikan kesehatan metode demonstrasi dan media video efektif terhadap kemampuan praktik SADARI di Pondok Pesantren Darul Hijrah Putri Martapura pada kelompok intervesi dan kelompok kontrol. Hasil ini sesuai dengan pendapat Notoatmodjo (2012) yang menyatakan bahwa dengan media promosi kesehatan, yaitu semua sarana atau upaya untuk menampilkan pesan atau informasi yang ingin disampaikan oleh komunikator, baik itu melalui media cetak, elektronika, maupun media luar ruang, dapat meningkatkan pengetahuan yang akhirnya diharapkan dapat berubah perilakunya kearah positif terhadap kesehatan.
Berdasarkan uji statistic didapatkan hasil bahwa ada perbedaan hasil post-test yang signifikan antara pendidikan metode demonstrasi dengan media video dan pendidikan kesehatan dengan media video saja. Hal ini disebabkan karena perbedaan media dan metode yang diberikan, dimana kelompok intervensi mendapatkan informasi dengan video dan demonstrasi dan kelompok kontrol hanya dengan video yang berhubungan dengan penggunaan panca indra sehingga berpengaruh dalam daya ingat dan penyerapan responden terhadap informasi yang diberikan. Pada kelompok kontrol diberikan pendidikan kesehatan dengan media video dimana menggunakan indra audio dan visual dan tingkat penyerapan responden $50 \%$. Sedangkan pada kelompok intervensi penggabungan media video (audio-visual) dan metode demonstrasi ditambah responden mengikuti gerakan SADARI yang dilakukan demonstrator (audio, visual dan melakukan secara nyata) memiliki tingkat penyerapan yang tinggi hingga $90 \%$. Hal ini merujuk pada teori piramida pengalaman Edgar Dale yakni, alat peraga disusun dengan prinsip bahwa pengetahuan yang ada pada manusia itu diterima dan ditangkap melalui panca indra dan semakin banyak panca indra yang digunakan semakin banyak pula pengetahuan yang diperoleh sehingga semakin tinggi pengetahuan tentang SADARI yang diserap semakin tinggi pemahaman tentang SADARI dan semakin tinggi kemampuan praktik SADARI responden. Penelitian ini sejalan dengan penelitian Pramadani (2017), yang menyatakan bahwa ada pengaruh efektifitas pendidikan kesehatan dengan metode demonstrasi dan media audio visual (video) terhadap ketrampilan praktik SADARI di SMK Batik 2 Surakarta.

Adapun perbedaan efektifitas antara pendidikan kesehatan metode demonstrasi dengan media video dan media video saja dalam penelitian ini dengan menggunakan uji statistic didapatkan nilai rata-rata hasil post-test kelompok intervensi yang diberikan pendidikan kesehatan metode demonstrasi dengan media video lebih besar daripada kelompok kontrol yang diberikan pendidikan kesehatan dengan media video saja. Hal ini menunjukkan bahwa pendidikan kesehatan metode demonstrasi dengan media video memiliki tingkat efektifitas lebih tinggi daripada video saja. 


\section{Kesimpulan}

1. Pendidikan kesehatan metode demonstrasi dengan media video efektif terhadap praktik SADARI di Pondok Pesantren Darul Hijrah Putri Martapura dimana sebagian besar responden mendapatkan nilai $100(32 \%)$ dan nilai terendah 61,1 (6\%) pada kelompok intervensi.

2. Pendidikan kesehatan metode demonstrasi dengan media video efektif terhadap praktik SADARI di Pondok Pesantren Darul Hijrah Putri Martapura dimana sebagian besar responden mendapatkan nilai 100 (26\%) dan nilai terendah 27,8 (3\%) pada kelompok kontrol.

3. Terdapat perbedaan keefektifan pendidikan kesehatan metode demonstrasi dengan media video dan pendidikan kesehatan media video saja terhadap praktik SADARI di Pondok Pesantren Darul Hijrah Putri Martapura.

\section{Saran}

1. Saran teoritis

Hasil penelitian ini dapat dijadikan sebagai tambahan literatur untuk melakukan tindakan keperawatan independent dalam mengurangi tingkat penderita dan kematian akibat kanker payudara pada wanita di Indonesia.

2. Saran praktis

\section{a. Bagi Remaja}

Teknik SADARI merupakan salah satu cara deteksi dini kanker payudara dan pencegahan dari kematian akibat kanker payudara. Melakukan SADARI sangat mudah, murah, praktis dan cepat. Diharapkan remaja putri melakukannya secara rutin.

b. Bagi Pondok Pesantren Darul Hijrah Putri Martapura

Penelitian ini diharapkan dapat memperkaya teknik pengajaran, pengetahuan, kemampuan dan dapat membantu meningkatkan kesehatan reproduksi remaja putri terutama kesehatan payudara.

c. Bagi Peneliti Selanjutnya

Peneliti lain dapat melakukan penelitian lanjutan dengan membandingkan pendidikan kesehatan menggunakan metode demonstrasi dan media video terhadap peningkatan kemampuan SADARI pada remaja putri.

\section{DAFTAR RUJUKAN}

Ardayani, T., \& Sinaga, C. F. (2016). Deteksi Dini Kanker Payudara Melalui Periksa Payudara Sendiri Di Sma Pasundan 8 Bandung Tahun 2016. Kartika-Jurnal IImiah Farmasi, 16-19.

Arsyad, Azhar. 2011. Media Pembelajaran. Jakarta: PT Raja Grafindo Persada..

Astuti, D. L. (2017). Efektivitas Penyuluhan Pemeriksaan Payudara Sendiri Dengan Media Video Dan Phantom Terhadap Praktik SADARI Pada Siswi SMP N 1 Naggulan Yogyakarta: Universitas As'aisyiyah Yogyakarta.

Dinkes. (2019). Penyakit Tidak Menular 2016, 2017 dan 2018. Banjarmasin: Dinas Kesehatan Kota Banjarmasin.

Djahmarah, S, B. (2010) Strategi Belajar Mengajar. Jakarta: Rineka Cipta

GLOBOCAN (2018). Cancer today. International Agency for Research on Cancer. http://gco.iarc.fr/ - Diakses Juli 2019.

Kementerian Kesehatan RI. (2013). Komite Penanggulangan Kanker Nasional. Panduan Penatalaksanaan Kanker Payudara. Jakarta: Kementerian Kesehatan Republik Indonesia.

Kementerian Kesehatan RI. (2013). Riset Kesehatan Dasar (RISKESDAS). Jakarta: Badan Litbang Kemenkes RI.

Kementerian Kesehatan RI. (2015). Buletin Jendela Data \& informasi kesehatan, semester 1, 2015.

Kementerian Kesehatan RI. (2015). Keputusan Menteri Kesehatan Republik Indonesia Nomor 796/MENKES/SK/ Tentang Pedoman Teknis pengendalian kanker Payudara Dan Kanker Leher Rahim. Jakarta: Kementrian Kesehatan Republik Indonesia.

Kementerian Kesehatan RI. (2016). Stop Kanker(Situasi Kanker Payudara).

Kementerian Kesehatan RI. (2017). Profil Kesehatan Indonesia 2016. Keputusan Menteri kesehatan Republik Indonesia. Jakarta.

Mubarak, WI. (2012). IImu Kesehatan Masyarakat. Jakarta : Salemba Medika

Notoatmojo S. 2012. Promosi Kesehatan dan Preilaku Kesehatan. Jakarta: PT Rineka Cipta. 
Pradani, et al. (2017). Efektifitas Pendidikan Kesehatan Melalui Media Audio Visual (Video) Dan Metode Demonstrasi Terhadap Ketrampilan Praktik Sadari Di Smk Batik 2 Surakarta. Karya Tulis IImiah Strata Satu, Sekolah Tinggi IImu Kesehatan 'Aisyiyah Surakarta, Surakarta.

Pramadani, A. D. (2017). Efektifitas Pendidikan Kesehatan Melalui Medao AudoVisual (Video) dan Metode Demosntrasi terhadap Keterampilan Praktik SADARI DI SMK Batik 2 Surakarta. Skripsi Strata satu: STIKES Aisyiyah Surakarta.

Primavera, I. R. C., \& Suwarna, I. P. 2014. Pengaruh Media Audio-Visual (Video) Terhadap Hasil Belajar Siswa Kelas XI Pada Konsep Elastisitas. Prosiding Seminar Nasional Pendidikan IPA FITK UIN Syarif Hidayatullah Jakarta, 11 September 2014

Purba, L. (2013). Pengetahuan Dan Sikap Mahasiswa Dalam Upaya Deteksi Dini Kanker Payudara Di Fakultas Keguruan Dan IImu Pendidikan Universitas Hkbp Nomensen Pematang Siantar.

Syaiful, Sagala. 2012. Supervisi Pembelajaran. Bandung : Alfabeta

Wahyuningtiyas, A. (2013). Faktor-Faktor Yang Berhubungan Dengan Keterampilan Melakukan SADARI Pada Remajaputri Didesa Giripensi Wates Kulon Porogo. Karya Tulis IImiah Strata Satu, Sekolah Tinggi IImu Kesehatan 'Aisyiyah Yogyakarta, Yogyakarya.

Widyastuti, Rahmawati, \& Purmaningrum. (2019). Kesehatan Reproduksi. Yogyakarta: Fitramaya.

Yakout. (2014). Awareness Knowledge and Practice of Breast Self Examination Among Groups of Female Nursing Students, Riyadh, Kingdom of Saudi Arabia. International Research Journal of Biological Sciences Vol.3 (2) pp 5863, ISSN 2278-3202.

Zen, J, Annisa. (2016). Pengaruh Penyuluhan Periksa Payudara Sendiri (SADARI) Terhadap Kemampuan Melakukan Praktik SADARI Pada Anggota Palang Merah Remaja SMAN 1 Jetis Bantul. Univeristas 'Aisyiah Yogyakarta. 